\title{
Amy Cook
}

\section{Cognitive Contagion: Thinking with and through Theatre}

Human beings have told stories for longer than we have been writing, doing math or creating art. Before we harnessed the horse or created an aqueduct, we pretended to be something we were not in order to tell about an alternate place and time. We came together as spectators, auditors and jointly attended the storyteller, who we knew was one of us but for tonight was someone else. Although the history of theatre and the arts tells us that periods of important theatrical and artistic development generally occur during times of relative peace and stability, humans have found enough value in this activity to keep it up. Theatre offers an opportunity for conceptual, intellectual, practical and social advancement because it takes advantage of the whole thinking organism; making sense of theatre has always required a kind of gestalt between the heart, mind and body, or more precisely, it always reminded us that those were never separate to begin with.

This experience of "aha", the pleasurable moment when I "get" something, some truth, on a deep level, is one that interests me here. This experience does not shake off easily. I remember crying during a production of George Bernard Shaw's Man and Superman when the characters climbed a red ladder against a white wall and, for a number of reasons I can no longer remember, I knew the play was adjusting my sense of scale and the impact of human hubris. I can recall a production of As You Like It, before I had read the play or thought I understood Shakespeare, when the audience and I all sat forward to listen differently when Rosalind said, "men have died from time to time, and worms have eaten them, but not for love". Just last year, I saw a performance by the UK's Forced Entertainment that defied my ability to make a story or even make much sense, but I laughed and knew I was being given a view of how to see human beings as more like a colony of ants than a community of individuals. The crying, sitting forward and laughing were not and cannot be separated from the meaning that came together for me during these performances. This is the argument I want to expound on here, the critical first step of a larger argument about thinking with theatre: what does it really mean to commit to a theory of embodied cognition?

To say that cognition is embodied means more than the brain is part of the body and thus impossible to fully separate. It means more than the brain is not 
a computer operating "off-site" and then sending messages to the body. It means that thinking is what happens when I am in my body. It means that imagining an eagle and seeing an eagle use many of the same cells. It means that the meaning carried by the shape my mouth takes in saying the word is part of my experience of the word, so that most people will share similar guesses as to what "kiki" and "bouba" mean because of what it feels like to say the made-up words. The state of the body is both an input into language interpretation and an output. As Gibbs (2005) says, "People's understandings of linguistic meanings are not divorced from their embodied experiences, but rather are fundamentally constrained by them in predictable ways". He articulates the "embodiment premise" as

\begin{abstract}
"People's subjective felt experiences of their bodies in action provide part of the fundamental grounding for language and thought. Cognition is what occurs when the body engages the physical, cultural world and must be studied in terms of the dynamical interactions between people and the environment. Human language and thought emerge from recurring patterns of embodied activity that constrain ongoing intelligent behavior. We must not assume cognition to be purely internal, symbolic, computational, and disembodied, but seek out the gross and detailed ways that language and thought are inextricably shaped by embodied action". (Gibbs, 2005)
\end{abstract}

Comprehending language is a full-bodied affair. We cannot rely on readings that disembody language and talk about meaning as a kind of semiotic code. We require a new look at the literature that moves us.

Embodied cognition seems like more of a facile or obvious idea than it is: everyone has had the experience of a smell reminding them of a something or an emotion closing out all logical thinking. However, these are all examples of the body serving as an input to cognition; you can argue that the cognition is embodied when all you mean is that thinking requires or is influenced by inputs from the body. This still views the mind or brain as the central force in "cognition". As Rhonda Blair and I put it in our introduction to Theatre, Cognition, Performance,

"Embodied cognition is not something that requires explicit physical movement or action; cognition is embodied when we add up receipts, get a glass of water for a thirsty friend or reach for the shampoo in the shower. To say that cognition is embodied is to say that what we have called 'thinking' requires the body and happens as it does because of the body we have. The problem is not with making our thinking or our performing more 'embodied' - thought is always embodied. The challenge is coming up with language to articulate what it has been all along: we have missed some of the nuances because our language looks for bodies and minds". (Blair \& Cook, 2016) 
Our language is older than our science; our language evolved to capture how thinking, feeling and being are-but even the very fact that I separated these three things out as useful dividing points reflects my conceptual structure. Imagine if, instead, I said "our language evolved to capture how we are when we labor and when we rest", "to capture thinking together versus thinking alone" or "to capture foot-self and hand-self and tongue-self". It can be hard to notice how our language constrains our thinking, but this is one of the critical insights of cognitive linguistics and embodied cognition.

Cognitive linguistics argues that thinking and speaking are metaphoric and creative. We use metaphors to understand something new and unknown, e.g., her love burned me and the math escaped me. The critical difference between the cognitive linguistics of George Lakoff, Mark Turner, Mark Johnson and Gilles Fauconnier (and many others) and the linguistics or generative grammar of people like Noam Chomsky is the body: for cognitive linguistics, these ways of speaking are always and ever a way of thinking as well. It is not that I first feel her love and then associate it or link it with fire; it is that the experience of love is understood with the same physical and neural systems that understand heat. Metaphor structures both language and thought, there is no literal meaning that receives primary attention, and all cognition and language are embodied. In Philosophy in the Flesh: The Embodied Mind and Its Challenge to Western Thought, Lakoff and Johnson (1999) argue that the "very structure of reason itself comes from the details of our embodiment". We then come to describe someone as "warm" without even perceiving the metaphor at work. These have been traditionally understood as "dead metaphors", metaphors that started out creative and now are no longer operational. This metaphor about different kinds of metaphors privileges "living" metaphors and masks the power and influence of "dead" metaphors. If "she's a warm person" involves a "dead metaphor", then it should not maintain a "living" relationship between the two kinds of warmth-it should be an association we know about because of etymology or the dictionary, not our bodies. However, research has shown that this is not the case. The way people talk about time can change if they are about to travel long distances (Boroditsky $\&$ Ramscar, 2002). When people use motion terms to talk about something that does not move- "the mountain range runs from California to Mexico"- they simulate motion when they are interpreting the sentence (Matlock, 2010). Language activates and moves us.

Thinking and speaking requires compression. Compression here is a term for the unconscious process by which we reduce the scale of something. This is what happens when we "turn the accomplishment of many years into an hour glass" as we do when we see a play and know that time may elapse between scenes. Compression is what we do when we see the crown onstage as more than a golden 
circle or when we point to a map of our town and say: "here we are". It is both a fundamental aspect of all cognition and a cornerstone of theatre. Understanding that our thinking is creative, embodied, metaphoric and metonymic means that there is not an absolute relationship between a word and its referent. This is not the linguistics behind semiotics, constructivism or deconstruction. Once we see the play and creativity in our thinking — as reflected in our language-we have a more expansive sense of what can be true and false. We come to see that the very foundations of what we came to imagine as our self and our world are tentative stories told to make sense of stimuli. Lakoff (1987) summarizes the value of this ideological reformulation of cognition and language:

"If we understand reason as being disembodied, then our bodies are only incidental to what we are. If we understand reason as mechanical-the sort of thing a computer can do-then we will devalue human intelligence as computers get more efficient. If we understand rationality as the capacity to mirror the world external to human beings, then we will devalue those aspects of the mind that can do infinitely more than that. If we understand reason as merely literal, we will devalue art".

Those of us whose life's work is the value and evaluation of art can benefit from the cognitive theories that place art in relationship to the body/mind and its language.

When I talk about cognition, I am always including the body and the emotions. Studying cognition only through images of the brain is almost like studying gravity in space, and there is evidence from neuroscience to support this. Embodied cognition, at this point, is not a radical claim-although I would argue that people use it without fully appreciating the entailments and consequences. Scientists and philosophers have generated theories of cognition that expand embodiment to argue that thinking happens beyond the body, with some arguing that there is very little in the way of representation in the brain at all. For some, thinking is skilful engagement with the environment. When people speak of $4 \mathrm{E}$ cognition, they are referring to the range of counters to the traditional cognitivist model (where thinking happens in the head as a series of calculation and instructions), from embodied, embedded, extended and enacted. While I am partial to the stronger claims in $4 \mathrm{E}$ cognition - that it is both extended in and enacted with the environment-here I want to focus on how a strong commitment to embodied cognition might alter how we understand theatrical innovation from the past and in the present. I do not believe that this commitment needs to place me in opposition to work in neuroaesthetics, but I do believe that any truly rich, complicated process or object of study requires more than one mode of inquiry.

I have not done empirical research into literature or theatre reception; I integrate the empirical research of others into a humanistic, historical and philosophical 
approach to literature and performance. Doing so does not "prove" a previous reading or analysis but can enrich or expand the questions available to scholars to ask about the work and the humans engaging with the work. For example, I have written about my chronic misunderstanding at the start of Richard III: the line "Now is the winter of our discontent" made me anticipate and assume a dark and miserable start to the play because I imagined winter being the apex of discontent's cold. Later in the sentence, I realized that Richard meant that winter is the end of a year of discontent (Cook, 2007). On the level of the syntax, I was wrong but on the level of the play and the character, I was right: for Richard, peace is a negative and fighting brings power and pleasure. This, perhaps, is just an idiosyncratic reading on my part: others perhaps anticipated summer as soon as Richard mentioned winter. We could conduct an experiment to find out, but we could start by questioning the value of the confusion in interpreting the rest of the play. Does this interpretive false start prepare us for a play where language slips from sense and where questioning our initial read on a phrase or an event is useful? We can move on with a shallow read of the phrase "winter of our discontent" and understand enough about the situation by the end of the soliloquy, or we can be stopped short by "made glorious summer" and return for a deeper read of the language that fooled us the first time. My point is not that experiments are necessary but rather that questioning how we make sense-and fail to make sense-of the poetry is fruitful avenue of research, both into the mind of the reader and the meaning of the language.

I want to understand the impact of performance on audiences. Of course, the term "audience" itself is a shorthand term for a group of singular, embodied minds acting as spectators, and when we think about what embodied spectatorship entails, complexities quickly become daunting. I want to understand how a room full of individual spectators can become a singular audience, laughing and responding as one. In a recent essay, I traced three different physical audience responses_-laughter, squirming and movement_-and argued that these physical reactions evidenced moments where the spectator perceived a truth or experience that fell outside what she might have rationally agreed to. In other words, when I laughed at Anna Deavere Smith's performance of a bull riding cowboy, my laughter "is a physical reaction indicative of an internal composition of meaning. So when Smith, as the bull rider, talks about his 'high tolerance for pain,' I am seeing it partially through her eyes, not just in her eyes" (Cook, 2015). Eventually, this strange laughter at the intersection of character/actor/spectator leads me to see the narrative and the idea of the self and character differently: "The 'characters' are not people stand-ins, essences temporarily housed in the body of an actor. It is a person staging for us the nodal points of character, of self, of other. The agency is systemic, the action is perception" (Cook, 2015). The laughter is not 
just the sign or evidence of comprehension, it is what the performance is calling for-the laughter is what it means. If the spectators did not laugh when Smith performed as this man, then they would not experience the pleasure of the multiple flights of perspective. This travel is the point, the meaning, the work of Anna Deavere Smith's work. The embodied experience of laughing is not incidental to the cognizing of the event; it is central. Let us take another example. Imagine you are watching an agon or debate onstage- perhaps Shakespeare's stichomythia between Richard and Ann in Richard III-and your gaze goes back and forth from one character to the other as they lob retorts at each other. Suddenly, one of the actors stops, pauses and you look from their silence to their partner. Your anticipation that the rhythm would continue is made evident in your gaze, and you know from this information that something changed in the scene. It was not the words; it was the startling change from words to silence that you felt as your expectations were not met. In order to place art and its value in context, we must think about the embodied user of art; what does the art afford? what does it invite? and what does it impart?

\section{Catching the [Cognition] of the King}

I have heard

That guilty creatures, sitting at a play,

Have by the very cunning of the scene

Been struck so to the soul that presently

They have proclaim'd their malefactions;

For murder, though it have no tongue, will speak

With most miraculous organ, I'll have these Players

Play something like the murder of my father

Before mine uncle. I'll observe his looks;

The play's the thing

Wherein I'll catch the conscience of the king. (Hamlet 2.2.588-605)

Hamlet believes that the king will display his guilt in reaction to the play because the "cunning of the scene" has been shown to strike guilty creatures "to the soul". This is quite an argument for the power of fiction and performance: like some kind of theatrical ipecac, the scene will evoke a powerful response when spectators recognize "something like" their situation staged for them. When the king cries for light, Hamlet takes this as a sign that the mousetrap worked and that the king's feelings of guilt were made manifest. The mousetrap thus works to shift the 
thinking of both of them: the king sees in the story of a slain king his own murder of his brother and Hamlet sees in the king's reaction, the truth of the ghost's narrative. Like Hamlet, we stage "something like" the difficult social/cultural/ cognitive challenges of our time in order to make new sense.

Elsewhere, I have argued that Shakespeare taught his audiences to think differently about character and self by staging metatheatrical moments where actor and character split (Cook, 2016). For their performance before the nobility, the Rude Mechanicals must figure out how to represent what they cannot present onstage. Starveling enters to explain that he is playing Moonshine: 'This lanthorn [lantern] doth the horned moon present;/Myself the man i' th' moon do seem to be' (5.1.245). Rather than just providing light and serving the players and audience as moonlight, it is important to Starveling to clarify what he represents: his character. The audience seems less interested in attending to his explained semiotics than they are in playing with his meaning; first, they make a horns/cuckold joke, and then, Theseus points out that if he were the man in the moon, he should be in the lantern, not holding it. Starveling's attempt to ground the meanings fails because it is superfluous - he assumes that his audience needs help in seeing the light of a lantern as the light of the moon. They can understand metonymy but do not need that here to understand the story of Pyramus and Thisby, so they interrupt to make jokes. Once he regains their attention, he perseveres in explaining the symbolic play at hand: 'All that I have to say is to tell you that the lanthorn is the moon, I, the man i' th' moon, this thorn-bush my thorn-bush, and this dog my dog' (5.1.257-9). Starveling changes the objects based on how they will perform within the theatrical frame. Shakespeare calls our attention to the epistemological joke by taking it to the extreme: mapping the lantern to the moon is on a continuum of absurd representations ending in the clearly unnecessary mapping of one dog to another dog. Shakespeare labels Starveling by his occupation and then has him announce his dog's character to the nobility. Whether or not Shakespeare's spectators - or any of us - have been to a play, we understand that one thing can be another, depending on how it is used in a given situation. By getting this joke, we notice this cognitive operation. Shakespeare is teaching us to build character.

Recently, I find myself in with spectators who are engaged in the environment of the theatrical experience: not asked to make meaning but given opportunities to enact an experience. Campbell Edinbrorough's book, Theatrical Reality, takes seriously the embodied spectator, embedded in space, and the role she plays in constructing the theatrical experience. Theatre is a medium that has both material and imagined realities, and Edinborough (2016) argues that it is the "interrelationship between different forms of space that enables the creative possibilities associated with theatrical performance". He explores historical works (Adolphe 
Appia, for one) and contemporary productions (Pina Bausch's Kontakthof, 1978) to provoke the reader into reconsidering "how performers, spectators and spaces come together to establish theatrical realities" (Edinborough, 2016). Many of these performances rely on a staging, a placing, of the spectator into the experience. This kind of performance puts the spectator into the scenic reality and strains and stretches the conventions of performer, author and spectator. Edinborough analyzes an experience he had at a performance wherein a character reached out to hold his hand and suddenly felt himself both in and out of the drama: "As the actress held my hand, I wondered who I was supposed to be, which made me wonder who her character thought I was" (Edinborough, 2016). This "corporeal alienation" made it difficult for him to distinguish between theatrical reality and his own reality. What Edinborough does not discuss, but that is my interest here, is what might be the cognitive/conceptual work of theatrical productions that stage the audience differently?

If I am brought to my seat by an usher and told to turn my phone off, unwrap my candy and sit quietly in the dark when the play begins, I have been staged as part of the performance. My role has been cast: "sit here, watch there". I may, like the king, imagine a relationship between what is on stage and my own life ("I also killed my brother" or "My parents also fought"), but the two are separated by distance, darkness and the "fourth wall". When theatre companies disrupt this reception relationship, spectators need to challenge their interpretive protocols. In Pan Pan's production of "The Rehearsal: Playing the Dane", the spectators are cast at a critical moment in a different role than "reader" of metaphoric experience; we are asked to physically stabilize the play's text by casting the title character.

Like many contemporary productions, the actors are onstage when we are led to our seats. They warm up, they read and they practice. A great dane-a dog, not the eponymous prince of Denmark — catches our attention, even if the actors do not. He is large and gorgeous-a small pony more than a dog. As anyone who knows anything about theatre anticipates: this dog will upstage just about anything else that happens onstage with him. A woman starts the play by walking forward with pages and the leash of the dog. She introduces herself as a local Shakespearean scholar and reads an essay on the instability of the text of the play and the instability of the character of Hamlet. She mentions the much-discussed textual instability between the three versions of Hamlet: the bad quarto, the "good" quarto and the folio. The tortuous textual history of Hamlet means that editors can compare the folios to the quartos to investigate mysteries that previous editors or directors had erased through choice or correction. For example, in the first quarto, the gravedigger's song refers to "such a ghest most meet" (Q1.16.34) although the Q2 and folio emend it to "guest". Kathleen Irace points out that 
"ghest" might be a deliberate combination of "ghost" and "guest", as, in an earlier scene, Horatio asks Hamlet to "ceasen" his admiration for awhile in order to take in Horatio's ghost report (Q1.2.106). "Season" - the choice of Q2 and the folio text—makes as much sense as "cease in", so perhaps, the Q1's combination allows both meanings to come to play. The scholar in Pan Pan's production refers to Hamlet's concern about his "too too sullied flesh": in the Folio Hamlet's flesh is "solid," in the first quarto, it is "sallied" and in the second quarto, his flesh is "sullied". Pan Pan's scholar wants to remind us of this indeterminacy as a key element to the play - a feature, not a bug. As expected, our attention returns again and again to the dog at her side_-and she periodically must pet him, calm him-but this works to support her argument rather than to diminish our attention. We get the joke, the Great Dane that is both prince and dog-the destabilization that happens in serious scholarly ways and accidents of time.

She leaves with the dog, and the actors line up and a director assigns parts to the men and women standing downstage. Without any evidence, he tells the spectators that they are missing an actor. He comes down into the house and casts a spectator to play a part. He hands him a script and asks him to read this part when they get to it. They read the scene-actors in street clothes and the audience member barely distinguishable from them except for the slightly more evident nerves he displays_-and stop it almost as soon as the spectator's lines are completed. He is thanked and returned to his place among us, the audience. The director goes behind a table and commences an audition. Who will play Hamlet? Three different actors audition for the role of Hamlet, by reading a soliloquy, or in the case of one actor, reading a monologue from Samuel Beckett's Endgame. Once the auditions are done, the director confers with his associates and then tells the audience that they cannot decide who to cast, so we must decide for them who will play Hamlet in tonight's production by coming onstage and standing behind the actor who, we believe, did the best job. We must put our bodies in the drama. Once we are all up there, squeezing onstage, laughing at our discomfort and smiling sheepishly at the actor we did not choose, the actor counts the bodies behind him and as he does so, he touches each of us. Again, we are cast, made part of his attempt to stabilize his count. Standing there as they decide who will be our Hamlet, we are made aware of, made complicit in, this always already failing of language and meaning to hold still.

This production of Hamlet did not sit still. From the dog on, the audience had to reorder the scenes and also hold characters attached to actors even when they switched parts or when the other two potential Hamlets seemed to ghost the actor selected by us this night. The director, though, prepared us for this involvement in meaning by casting us as casting directors and by making us use our bodies as extensions of our voice/vote. We were not ever independent 
of the meaning of this Hamlet. Putting together, the meaning of this Hamlet involved accessing all these elements of the evening's performance; it required us to shake loose our assumptions that we know what it means to make meaning. This, I believe, is how the production-and lots of other contemporary theatrical productions-is helping us to think differently. This Hamlet is not about the main character's internal psychology_his Freudian feelings for his mother, for example. This Hamlet is not about the possibilities of individualism in a growing modern world. It is not about the power of God to right the rot of the countrythe providence of the fall of a sparrow. It feels like it is about the power of the group to stabilize temporary meanings. This Hamlet reminds me that characters can be cast and recast. It gives me a tool to imagine a world without a stable self or clear cause and effect. It calls my attention to my body, to a refusal to tell a clear story or to reward psychological readings. It is theatre that I may not understand, in a traditional way, but it gives me a way to understand a new way of thinking about the world around me. It is theatre I can use.

\section{Summary}

Theatre offers an opportunity for communities to think with and through fiction. We come together to hear and tell stories because it is moving, both in the literal and the figurative sense: it changes us. Theories from cognitive science of embodied cognition make clear that making sense of theatre is a full-bodied affair. In this essay, I argue that we can see moments when theatre invited its audience to think in new ways by shifting theatrical conventions. I explore how a contemporary production of Hamlet, Pan Pan's production of "The Rehearsal: Playing the Dane", brings its audience to question the stability of the self and text by altering the conventions around casting and representation. This is theatre that I may not understand in a traditional way, but this gives me a way to understand a new way of thinking about the world around me. It is theatre I can use. Keywords: Embodied cognition, Hamlet, cognitive science, Shakespeare, theatre.

\section{Kognitive Ansteckung: Denken mit und durch Theater}

\section{Zusammenfassung}

Theater bietet der Gesellschaft die Möglichkeit des Denkens mit und durch Fiktion. Wir kommen zusammen um Geschichten zu hören und zu erzählen, weil es uns - sowohl im literarischen als auch figurativen Sinn - bewegt: es verändert uns. Erkenntnistheorien über verkörperlichte Wahrnehmung machen klar, dass es eine ganzkörperliche Angelegenheit ist, aus einem Theaterabend Sinn zu ziehen. In diesem Beitrag lege ich dar, dass wir Momente erkennen können, in denen das Theater sein Publikum dazu einlädt, in neuen Bahnen zu denken, indem es theatrale Konventionen verändert. Ich untersuche, wie eine zeitgenössische Aufführung von Hamlet, Pan Pan's Produktion “The Rehearsal: Playing the Dane", durch Veränderung der Konventionen bei Besetzung und Darstellung die Zuseher dazu bringt, die Stabilität des Selbst und des Textes in Frage zu stellen. Es ist dies ein Theater, das ich in einem traditionellen Sinn vielleicht nicht verstehe, das mir 


\section{Cook, Cognitive Contagion: Thinking with and through Theatre}

aber einen Weg zum Verständnis einer neuen Art des Denkens über die Welt, die mich umgibt, eröffnet. Es ist Theater, das ich gebrauchen kann.

Schlüsselwörter: Körperliche Wahrnehmung, Hamlet, Erkenntnistheorie, Shakespeare,

Theater.

\section{References}

Blair, R., \& Cook, A. (Ed.) (2016). Theatre, Performance and Cognition: Languages, Bodies and Ecologies. London, UK: Methuen.

Boroditsky, L., \& Ramscar, M. (2002). The roles of body and mind in abstract thought. Psychological Science, $13(2), 185-9$.

Cook, A. (2007). Interplay: The Method and Potential of a Cognitive Scientific Approach to Theatre. Theatre Journal, 59 (4).

Cook, A. (2015). Bodied Forth: A cognitive scientific approach to performance analysis. In N. George-Graves (Ed.). The Oxford Handbook of Dance and Theater. Oxford: Oxford University Press.

Cook, A. (2016). King of Shadows: Early Modern Characters and Actors. In P. Budra, \& C. Werier (Ed.). Shakespeare and Consciousness. London: Palgrave Macmillan.

Edinborough, C. (2016). Theatrical Reality: Space, Embodiment and Empathy in Performance. Bristol, UK: Intellect.

Gibbs, R. W. Jr. (2015). Embodiment and Cognitive Science. New York: Cambridge University Press.

Lakoff, G. (1987). Women, Fire, and Dangerous Things: What Categories Reveal about the Mind. Chicago: University of Chicago Press.

Lakoff, G., \& Johnson, M. (1999). Philosophy in the Flesh: The Embodied Mind and Its Challenge to Western Thought. New York: Basic Books.

Matlock, T. (2010). Abstract motion is no longer abstract. Language and Cognition, 2 (2), 243-260.

Amy Cook was born in 1970. Her most recent book is Building Character: The Art and Science of Casting (University of Michigan Press, 2018). She has also written Shakespearean Neuroplay (Palgrave Macmillan, 2010), co-edited (with Rhonda Blair) Theatre, Performance and Cognition: Languages, Bodies and Ecologies (Methuen 2016) and has (or will have) essays published in The Oxford Handbook of Dance and Theater (2015), The Oxford Handbook of $4 E$ Cognition (2018), The Routledge Companion to Theatre, Performance, and Cognitive Science (2018) and The Cambridge Companion to Shakespeare's Language (forthcoming).

Address: 14 Archer Dr., Stony Brook, NY 11790, USA

Email: Amy.cook@stonybrook.edu 